Jurnal Abdimas Kesehatan (JAK) Vol 4, No 1, Januari, 2022

Doi : $10.36565 /$ jak.v4i1.211

p-ISSN: 2655-9266

e-ISSN: 2655-9218

\title{
Kompres Serai Hangat Mengurangi Nyeri Rheumatoid Arthritis
}

\author{
Dwi Kartika Pebrianti ${ }^{1}$, Mila Triana Sari ${ }^{2}$ \\ ${ }^{1}$ Program Studi S1 Keperawatan, STIKes Baiturrahim Jambi \\ ${ }^{2}$ Program Studi Profesi Ners, STIKes Baiturrahim Jambi \\ Email :dwiekartika86@gmail.com
}

Submitted : 19/03/2021

Accepted: 08/01/2022

Published: 28/01/2022

\begin{abstract}
Rheumatoid arthritis occurs in 0.5-1\% of the adult population in developed countries. Based on data from Riskesdas (2018), there is an increase in joint disease, originally there was $7.3 \%$, increased to 11.9\%. The high incidence of Rheumatoid Arthritis is influenced by many factors, namely age, gender, genetics, sex hormones, and immunity. Rheumatoid arthritis should not be ignored, because it will damage the joints which cause severe pain. One of the measures that have been shown to be effective non-pharmacologically to reduce pain is to warm the affected joint. Warm compresses can be used in the treatment of pain and relax tense muscles. Plants that have substances as warming, antiinflammatory and can increase blood flow such as lemongrass. The purpose of this activity is to provide education about rheumatoid arthritis and how to reduce pain by applying warm lemongrass compresses to residents in Lebak Bandung village. This service activity was carried out on 29-30 September 2020, by visiting the homes of residents who were the target of the activity. The target is the residents of Lebak Bandung village as many as 20 people. This activity consists of providing education with leaflet media and demonstrations using models. After education, all targets can understand and be able to demonstrate the application of warm lemongrass compresses. It is recommended that educational activities can be carried out routinely regarding health problems that are needed by the community
\end{abstract}

Keywords: application of warm lemongrass compress, education, rheumatoid arthritis

\begin{abstract}
Abstrak
Rheumatoid arthritis terjadi pada $0,5-1 \%$ populasi orang dewasa di Negara maju. Berdasarkan data Riskesdas (2018) terlihat peningkatan penyakit sendi, semula ada sebanyak 7,3\% meningkat menjadi 11,9\%. Tingginya angka kejadian Rheumatoid Arthritis dipengaruhi oleh banyak faktor yaitu usia, jenis kelamin, genetik, hormon seks, serta imunitas. Penyakit rheumatoid arthritis baiknya tidak dibiarkan, karena akan merusak sendi yang menimbulkan nyeri hebat. Salah satu tindakan yang terbukti efektif untuk mengurangi nyeri secara non-farmakologi adalah dengan menghangatkan persendian yang sakit. Kompres hangat dapat digunakan pada pengobatan nyeri dan mereleksasikan otot-otot yang tegang. Tanaman yang memiliki zat sebagai penghangat, anti radang dan dapat memperlancarkan aliran darah seperti serai. Tujuan dari kegiatan ini adalah memberikan edukasi tentang penyakit rheumatoid Arthritis dan cara mengurangi nyeri dengan penerapan kompres hangat serai kepada warga masyarakat di kelurahan Lebak Bandung. Kegiatan pengabdian ini dilaksanakan pada tanggal 29-30 September 2020, dengan mendatangi rumah-rumah warga yang menjadi sasaran kegiatan. Sasaran adalah warga masyarakat kelurahan Lebak Bandung sebanyak 20 orang. Kegiatan ini terdiri dari pemberian edukasi dengan media leaflet dan demonstrasi menggunakan model. Setelah dilakukan edukasi seluruh sasaran dapat memahami dan mampu mendemonstrasikan penerapan kompres hangat serai. Disarankan agar kegiatan pemberian edukasi dapat dilakukan secara rutin mengenai permasalahan kesehatan yang diperlukan oleh masyarakat
\end{abstract}

Kata Kunci: edukasi, penerapan kompres hangat serai, rheumatoid arthritis 


\section{PENDAHULUAN}

Rheumatoid Arthitis (RA) adalah penyakit autoimun progresif dengan imflamasi kronik yang menyerang sistem muskuloskletal namun dapat melibatkan organ dan sistem tubuh secara keseluruhan, yang ditandai dengan pembengkakan, nyeri sendi serta destruksi jaringan synovial yang disertai gangguan pergerakan diikuti premature (Mclnnes,2011).

Menurut data WHO (2016), sebanyak 335 juta penduduk di Dunia yang mengalami rematik. Menurut Arthritis Foundation (2015), sebanyak 22\% atau lebih dari 50 juta orang dewasa di Amerika Serikat berusia 18 tahun atau lebih didiagnosa arthritis. Dari data tersebut sekitar 3\% atau 1,5 juta orang dewasa mengalami Rheumatoid arthritis. Rheumatoid arthritis terjadi pada 0,5-1\% populasi orang dewasa di Negara maju. Berdasarkan data Riskesdas tahun 2018 tahun 2018 terlihat peningkatan penyakit sendi sebanyak $7,3 \%$ meningkat menjadi 11,9\%. Tingginya angka kejadian Rheumatoid Arthritis dipengaruhi oleh banyak faktor yaitu usia, jenis kelamin, genetik, hormon seks, serta imunitas (Nugroho, 2014).

Rheumatoid arthritis akan mengganggu aktivitas sehari-hari, sehingga tidak bisa mempengaruhi kondisi psikologis. Penyakit rheumatoid arthritis baiknya tidak dibiarkan, karena akan merusak sendi yang menimbulkan nyeri hebat. Terapi farmakologis penyakit radang sendi berupa pemberian analgetik, anti inflamasi nonsteroid, kortikosteroid, dan obat anti Rheumatoid. Sedangkan Salah satu tindakan yang terbukti efektif untuk mengurangi nyeri secara non-farmakologi adalah dengan menghangatkan persendian yang sakit (Pratintya, 2012). Kompres adalah suatu metode penggunaan suhu hangat setempat yang menimbulkan beberapa efek fisiologi. Kompres hangat dapat digunakan pada pengobatan nyeri dan mereleksasikan otototot yang tegang. (Wurangian, 2014). Tanaman yang memiliki zat sebagai penghangat, anti radang dan dapat memperlancarkan aliran darah seperti serai (Pratintya, 2012).

Dalam buku herbal Indonesia disebutkan bahwa khasiat tanaman serai mengandung minyak atsiri yang memilki sifat kimiawi dan efek farmakalogi yaitu rasa pedas dan bersifat hangat sebagai anti radang dan menghilangkan rasa sakit yang bersifat analgesik serta melancarkan sirkulasi darah dan diindikasikan untuk mengurangi nyeri sendi, nyeri otot, badan pegelinu dan sakit kepala. (Hidayat \& Napitupilu, 2015). Terapi kompres hangat dengan kombinasi serai ini telah dibuktikan dari The Science and Tecnology. Dimana serai memiliki senyawa analgetik yang dapat mengurangi rasa nyeri akibat arthritis rheumatoid (Hembing, 2007).Sejalan dengan penelitian (Fatmawati \& Ariyanto, 2021) dijelaskan bahwa mempunyai kompres serai memiliki pengaruh yang signifikan terhadap penurunan intensitas nyeri arthritis remathoid pada lansia di PSTW kota Jambi.

Kegiatan pengabdian masyarakat dilakukan pada sasaran yakni warga masyarakat di kelurahan Lebak Bandung Kecamatan Jelutung Kota Jambi yang berjarak $\pm 2 \mathrm{~km}$ dari Institusi Stikes baiturahim jambi. Gambaran demografi penduduk di kecamatan Jelutung berjumlah 63.792 jiwa, dengan tingkat kepadatan penduduk mencapai $8.055 \mathrm{jiwa} / \mathrm{km}$ (BPS kota Jambi, 2019). Dari data tersebut yang terdeteksi memiliki riwayat hipertensi, rematik, diabetes mellitus dan gastritis, namun belum bisa diperkirakan angka kejadian pastinya. 


\section{TARGET DAN LUARAN}

Khalayak sasaran yang dijadikan untuk kegiatan ini adalah warga kelurahan Lebak Bandung sebanyak 20 orang. Luaran kegiatan ini adalah publikasi pada jurnal ber-ISSN, publikasi di media sosial dan adanya penerapan kompres serai hangat yang dilakukan warga yang telah menjadi sasaran kegiatan ini.

\section{METODE PELAKSANAAN}

Metode pendekatan untuk mengatasi masalah:

a. Koordinasi dengan Puskesmas Simpang Kawat tentang hasil rencana kegiatan dalam upaya penanganan masalah kesehatan,

b. Sosialisasi, komunikasi dan informasi ke warga mengenai rencana kegiatan melalui undangan dan bekerjasama dengan kader setempat

c. Sosialisasi mengenai terapi kompres serei hangat terhadap Rematik menggunakan media leaflet.

d. Memberikan leaflet yang tentang terapi kompres serei hangat terhadap Rematik. Prosedur tindakan kompres serei hangat,

1. Cuci bersih tanaman serai dengan air mengalir dan tiriskan hingga kering

2. Masukkan 7 batang serai ke dalam panci yang berisi air $1500 \mathrm{ml}$ air

3. Rebus hingga air suhu derajat 46 celcius

4. Rebusan air serai dapat digunakan untuk kompres hangat

5. Ambil waslap maukkan di baskom berisi air hangat lalu diperas

6. Kompres di tempat tubuh yang nyeri selama 10 menit

7. Kompres kembali bila nyeri tidak teratasi

\section{HASIL DAN PEMBAHASAN}

Kegiatan pengabdian masyarakat dengan tema "Kompres Serai Hangat Untuk Mengurangi Nyeri Rheumatoid Arthritis Di Kelurahan Lebak Bandung Kota Jambi telah terlaksana pada tanggal 29 dan 30 september 2020.

Peserta kegiatan pengabdian masyarakat ini berjumlah 20 orang dan tim yang terdiri dari 2 mahasiswa. Tempat pelaksanaan di kelurahan Lebak Bandung dengan mendatangi rumah-rumah warga yang dinilai perlu diberikan penjelasan tentang penerapan kompres serei hangat, setelah dijelaskan secara teori, di demonstrasikan cara pelaksanaan mengompres serei hangat dengan media yang digunakan yakni Leaflet yang diberikan kepada sasaran/warga. Adapun tujuan dari kegiatan ini adalah untuk mensosialisasikan bagaimana penerapan kompres hangat terhadap rheumatoid arthritis sehingga saat nyeri timbul bisa berkurang.

Pelaksanaan pengabdian masyarakat ini mengisyaratkan tingginya minat masyarakat terhadap status kesehatan anggota keluargnya, hal ini dibuktikan dengan banyaknya pertanyaan yang sampaikan tentang topic yang diberikan yakni Kompres Serai Hangat terhadap Penderita Rheumatoid, misalnya pertanyaan bagaimana cara mengatasi nyeri rheumatoid, apa saja hal yang bisa dilakukan untuk mengatasi keluhan nyeri pada penderita Rheumatoid, dan masih banyak lagi. Hal ini menunjukkan bahwa masyarakat sangat peduli dengan kesehatan masyarakat yang membutuhkan informasi-informasi tentang masalah kesehatan yang kadang-kadang masih kurang pemahamanya. Oleh karena itu, kegiatan semacam ini sangat diperlukan bagi masyarakat dengan materi yang menyesuaikan dengan permasalahan yang dialami oleh masyarakat di daerah tersebut. 
Rheumatoid arthtis mengenai sendisendi kecil pada tangan dan kaki, selain itu rheumatoid arthtris jg bisa mengenai organorgan luar seperti kulit,jnatung, paru-paru dan mata. Mortalitas terjadi akibat adanya komplikasi kardiovaskuler, penyakit ginjal, keganasan dan adanya komordibitas. Faktor resiko dalam peningkatan terjadinya rheumatoid arthritis antara lain jenis kelamin perempuan, ada riwayat keluarga menderita rheumatoid arthritis, umur, paparan salisiat dan merokok (Sudoyo, 2017).

Penyakit rheumatoid arthritis baiknya tidak di biarkan ,karena akan merusak sendi yang menimbulkan nyeri hebat sehingga bisa mengganggu aktivitas sehari-hari. Jika dibiarkan tentu saja bisa mempengaruhi kondisi psikologis . Metode penghilang nyeri adalah melalui terapi komplementer yang sering digunakann adalah tehnik relaksasi, distraksi dan kompres hangat (Brunner\&Suddarth,2013).

Salah satu alternatif menghilangkan nyeri rheumatoid arthritis adalah dengan terapi komplementer salah satunya adalah kompres serai hangat, seperti penelitian yang dilakukan oleh Hyulita (2013) pengaruh kompres serai hangat terhadap penurunan nyeri rheumatoid arthritis pada lanjut usia di kelurahan Tarok Dipo Wilayah Kerja Puskesmas Guguk Panjang Bukittinggi.

Tanaman serai terkandung suatu enzim yaitu enzim siklo-oksigenase yang dapat mengurangi peradangan yang diserap melalui kulit pada daerah yang meradang/ bengkak pada penderita rheumatoid arthritis , selainitu serai juga memiliki efek farmakologis yaitu rasa pedas yang bersifat hangat, efek hangat ini merangsang sistem effektor sehingga mengeluarkn signal yang akan mengakibatkan terjadinya vasodlitasi perifer. Perubahan ukuran pembuluh darah diatur oleh pusat vasomotor pada medulla oblongata dari tangkai otak, dibawah pengaruh hipotalimik bagian anterior sehingga terjadi vasodilatasi . terjadinya vasodilatasi ini menyebabkan aliran darah kesetiap jaringan khususnya yang mengalami radang dan nyeri bertambah, sehingga terjadi penurunan nyeri pada jaringan yang meradang.

Kondisi pandemi seperti sekarang ini, mempengaruhi pemberian pelayanan kesehatan di fasilitas pelayanan kesehatan masyarakat, seperti Puskesmas maupun Rumah Sakit. Salah satu faktornya karena kekhawatiran masyarakat terhadap penularan virus corona di pelayanan kesehatan masyarakat yang tentunya mempunyai resiko yang lebih tinggi. Hal ini mendorong masyarakat untuk dapat mengatasi keluhan kesehatan yang dirasakan oleh anggota keluarganya. Misalnya dengan memanfaatkan pengobatan tradisional yang bahan dan cara mendapatkannya lebih mudah. Pelaksanaan pengabdian masyarakat yang dilakukan oleh civitas akademi STIKES Baiturrahim ini, setidaknya berkontribusi untuk memberikan informasi penting dan ilmiah berkaitan dengan membantu masyarakat mendapatkan solusi atas permasalahan kesehatan yang dihadapi, khususnya masalah rheumatoid yang masih banyak dialami oleh masyarakat pada umumnya.

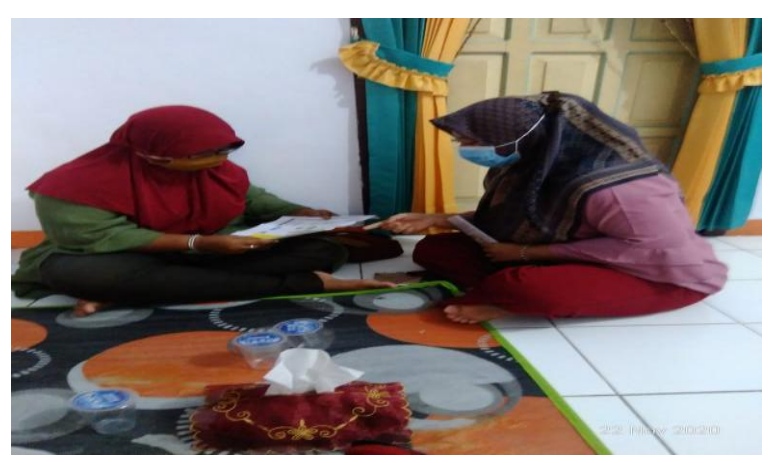

Gambar 1.Pemberian Edukasi 


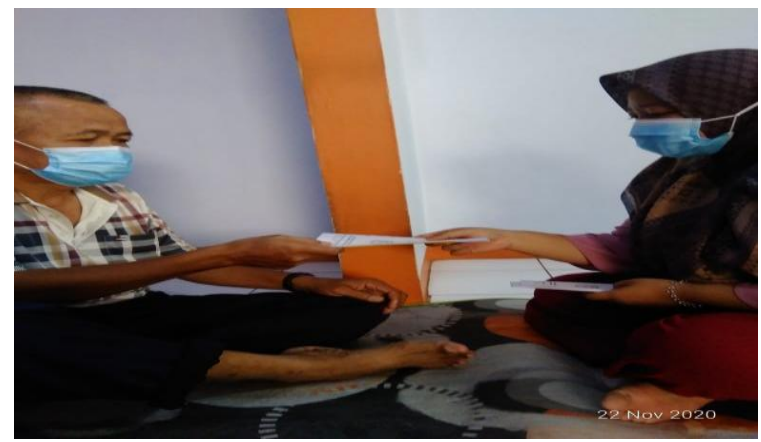

Gambaran 2.Pemberian Leaflet

\section{KESIMPULAN DAN SARAN}

\section{Kesimpulan}

Pelaksanaan kegiatan pengabdian masyarakat dengan judul Penerapan kompres hangat serai di warga kelurahan Lebak Bandung yang dilakukan oleh dosen dan mahasiswa STIKBA berjalan dengan baik. Pelaksanaan pengabdian masyarakat ini menyesuaikan dengan kondisi lingkungan di tengah pandemic Covid-19, yakni menghindari kerumunan dan tetap menerapkan standar protokol kesehatan dengan memakai masker dan menjaga jarak. Pelaksanaan dilakukan selama 2 hari yaitu mulai tanggal 29 September hingga 30 September 2020 dengan menyebarkan leaflet dan mendatangi rumah warga yang menjadi sasaran dalam kegiatan ini. Warga peserta dalam kegiatan ini sangat antusias mengikuti kegiatan, dan berharap dapat sering dilakukan kegiatan seperti ini.

\section{Saran}

Perlu dilakukan kegiatan secara rutin dan terjadwal khususnya pendidikan kesehatan di kelurahan Lebak Bandung tentang permasalahan kesehatan lainnya yang berkaitan dengan kondisi lingkungan.

\section{UCAPAN TERIMA KASIH}

Ucapan terimakasih kepada ketua RT dan perangkat serta kader kelurahan Lebak Bandung yang telah menfasilitasi kegiatan ini sampai selesai dan kepada Stikes baiturahim Jambi yang telah mendanai kegiatan pengabdian ini.

\section{DAFTAR PUSTAKA}

Arthritis Foundation, 2015, News From the Arthtritis Foundation: Rheumatoid Arthritis fact Sheet, Http://jupiterinletcolony.org/upload s/Rheumatoid_Arthritis_Fact_Sheet. pd

Badan Pusat Statistik (BPS), Jambi dalam Angka 2019. Catalog 1102001.1571.

file:///D:/idk\%20pemeriksaan $\% 20 \mathrm{p}$ enunjang/Kota_Jambi_Dalam_Ang ka_2019.pdf

Brunner \& Suddarth. 2013. Buku Ajar Keperawatan Medikal Bedah. Alih Bahasa.dr.H.Y.Kuncara.EGC: Jakarta

Hembing,W.2007. Atasi Asam Urat dan Rematik Ala Hembing. Jakarta :Puspa Swara

Hidayat, S. \& Napitupulu, R. (2015). Kitab tumbuhan obat. Jakarta: Penebar Swadaya

Mclnnes, L.B, Schett,G.2009. The pathogenesis of Rheumatoid Arthritis, N Engl J Med, Vol.365,pp.2205-19

Nugroho Wahyudi. (2014). Keperawatan gerontik dan geriatrik Edisi 3. Jakarta : ECG

Pratintya, A, D, \& Harmilah, H. 2012. Pengaruh pemberian kompres hangat terhadap nyeri persendian osteoatritis pada lanjut usia di Panti Werdha. Dharma Ponggalan Umbulharjo Yogyakarta. Doctoral 
Jurnal Abdimas Kesehatan (JAK) Vol 4, No 1, Januari, 2022 Doi : $10.36565 /$ jak.v4i1.211

p-ISSN: 2655-9266

e-ISSN: 2655-9218

dissertation. STIKES Aisysiyah Yogyakarta.
Akademika Baiturrahim Jambi, 10(1), 1. https://doi.org/10.36565/jab.v10i1.218

Riskesdas, 2018. Riset Kesehatan dasar. Wurangian. (2014). Pengaruh kompres Jakarta hangat terhadap penurunan skala

Fatmawati, T. Y., \& Ariyanto, A. (2021). Efektifitas Terapi Kompres Jahe dan Kompres Serai Hangat untuk Menurunkan Intensitas Nyeri Arthritis nyeri pada penderita Gout Arthitis di Wilayah Kerja Puskesmas Bahu, Menado. Jurnal e-Biomedik, ejournalunsrat.ac.id

Rheumatoid pada Lanjut Usia. Jurnal 